Thi-Qar Medical Journal (TQMJ):Vol.(19), No.(1), 2020

Web Site: https://jmed.utq.edu.iq

Email:utjmed@utq.edu.iq

ISSN (Print):1992-92 18, ISSN (Online):1992-92 18

DOI: https://doi.org/10.32792/utq/utjmed/19/1/3/0

\title{
Types, Characters and Trend of Congenital Anomalies in Thi-Qar / 2 years assessment
}

\author{
Falah Abd Basher Al-Hamdani DCH \\ Khudhair Abbas Salih DCH \\ Suad Saddam Salih DGO
}

\begin{abstract}
:
Congenital anomalies is structural or functional abnormalities present at birth. A total of 88 infants with different types of birth defects were included in this study, The data were collected in the period between 2/1/2017 to 31/12/2018 in Al-Nasiriya city/south of Iraq under the aim and title of detection of the types, trend and characters of congenital anomalies, after full ethical approval data were collected using a structured questionnaire. The highest rate was detected among males for the year 2018, while the highest percentage was among females in 2017. As well, the highest rate for infants weighing > 4kg was the highest in $2017(70 \%)$, while the high percentage of group $<4 \mathrm{~kg}(37.5 \%)$ was seen in 2018, The CS comprise high percent of delivery than NVD under $(\mathrm{P}<0.05)$. While the higher percentage was for spina bifida (0.88\%) in 2018, followed by hydrocephalus and cleft lip $(0.71 \%)$.while distribution was of multiple distortions, the rate was high $(0.46 \%)$ in 2017 . While distribution was of CHD and pul Atresia, the rate was high(0.5) in 2017 and 2018. Also, The results of this study were significant (p 0.0341) between percent of death in 2017 and 2018. The study conclude the necessity to provides important background information for potential prevention and better management of female who may have children with birth defects and the importance of further researches is required to determine the factors responsible for different types of birth defects.
\end{abstract}

Keywords: Congenital anomalies, C/S,NVD, ThiQar, 2017-2018

\section{Introduction:}

Congenital anomalies are congenital a defects occurs during the developmental period of embryo. Structural or functional abnormalities occur before birth and are also called birth defects[1]. Congenital anomalies are classified into two types, the first type affected a single organ system or part of the body, while the second type affected more than one organ system or body part[2]. Congenital anomalies spread widely throughout the world

ranging from $1.07 \%$ in Japan to $4.3 \%$ in Taiwan, Where this conditions accounted for 510,400 deaths and outbreaks in 2010 as it began to increase with the advancement of years[3]. Also, there is a study in Europe that confirmed the correlation of coronary heart 
Web Site: https://jmed.utq.edu.iq

ISSN (Print):1992-92 18, ISSN (Online):1992-92 18 DOI: https://doi.org/10.32792/utq/utjmed/19/1/3/0
Email:utjmed@utq.edu.iq diseases with congenital malformations, especially musculoskeletal deformities, are the most frequent[4].As there is a study conducted in the three clinics in the Fallujah General Hospital/Iraq, it showed high rates of congenital anomalous births and that some serious genetic exposures have affected and are still affecting the towns people[5]. Where there is a topics verify that the consequences of uranium and thorium in the wars that took place in Iraq has a significant negative crash on the incidence of birth defects in infants, and they have proven that there is increasing distress about the prevalence of birth defects in Iraq, especially the Thi-Qar province [6].Congenital anomalies were recognized in terms of defects in the physical structure or shape generally at birth or through the first weeks of life. It has been definite as a defect, i.e. an irreversible condition that arise in a child before birth wherever there is sufficient variation in the number, location, size, or usual form of any part and organ [7].Congenital malformations can happen due to a several causes involving genetic conditions, toxic substances, poorly nutrition, alcohol uptake by pregnant or other unclear reasons[8]. Increase facts about the occurrence of congenital anomalies is necessary to documenting alterations over time, achieve a baseline rates and identifying evidence to the etiology of state, also helps to plan and assessment antenatal screening for these defects[9]. This study was conducted to determine and compare the frequency, types, and some factors that associated with birth defects in two years under study (2017 and 2018).

\section{Methodology:}

This study was designed as a prospective cross sectional study, it was conducted in AlNasiriyah/south of Iraq in Bint Al-Huda teaching hospital and Al-Musawi hospital (maternity and Pediatrics), where the data of congenital anomalies of infants were collected between 2/1/2017 to 31/12/2018. The congenital anomalies were diagnosed by obstetrician and pediatrician, the type of deformity found in each infant is also was determined. All data about the cases of birth defects and deaths were recorded during the study period, as it included the number of children in the year (2017) 40 cases while in (2018) 48 cases, and data was collected even in the least 37 weeks of pregnancy or more than 37 weeks. The data also included sex, weight at birth, types of delivery, gestational age and the number of deaths during both years. A full ethical consideration had been implemented including the verbal consent from the parents, SPSS version 23 had been used, $P$ values less than 0.05 was consider as significant.

\section{Results:}

The result showed that there are 88 cases over two years fitted for the record of cases of congenital anomalies, there was a high percentage in the male gender in 2018 was $27(56.25 \%$ ), while the female percentage was high in 201723 (57.5\%).Also, the percentage of hermaphrodite was found in 2018 2(4.16\%), while there was no hermaphrodite ratio in 2017.The weight of infants showed the highest percentage in infants weighing less than $>4 \mathrm{~kg}$ was $28(70 \%)$ in 2017, and the highest proportion in 2018 was 30 (62.5\%), while in $<4 \mathrm{~kg}$, the highest proportion in 2018 was 18 $(37.5 \%)$.The results also showed that the high percentage of $\mathrm{C} / \mathrm{S}$ in both years were 29 (72.5\%) and $31(64.58 \%)$ in 2017 and 2018, 
Web Site: $\underline{\text { https://jmed.utq.edu.iq }}$

\section{ISSN (Print):1992-92 18, ISSN (Online):1992-92 18}

DOI: https://doi.org/10.32792/utq/utjmed/19/1/3/0

respectively when compared with NVD. The results illustrated nearest proportion of

gestational ages $<37$ weeks in both years $(40$ and $31.25 \%)$. While the gestational age $>37$ weeks were records (60 and68.75\%) in 2017

\section{Email:utjmed@utq.edu.iq}

Table (1) Distribution congenital anomalies in the 2 years under this study

\begin{tabular}{|l|l|l|l|l|}
\hline Characters & $\mathbf{2 0 1 7}$ & \multicolumn{2}{l|}{$\mathbf{2 0 1 8}$} \\
\hline So. & & $\%$ & No. & $\%$ \\
\hline Male & 17 & 42.5 & 27 & 56.25 \\
\hline Female & 23 & 57.5 & 19 & 39.59 \\
\hline Hermaphrodite & 0 & 0.0 & 2 & 4.16 \\
\hline Birth wt. & & & & \\
\hline$>$ 4kg & 28 & 70 & 30 & 62.5 \\
\hline$<4$ kg & 12 & 30 & 18 & 37.5 \\
\hline Delivery & & & & \\
\hline CS & 29 & 72.5 & 31 & 64.58 \\
\hline NVD & 11 & 27.5 & 17 & 35.42 \\
\hline Gestational age & & & & \\
\hline$<37$ weeks & 16 & 40 & 15 & 31.25 \\
\hline$>\mathbf{3 7}$ weeks & 24 & 60 & 33 & 68.75 \\
\hline Delivered died & 37 & 92.5 & 19 & 39.58 \\
\hline Total & 40 & 100 & 48 & 100 \\
\hline
\end{tabular}

and 2018 respectively. The death rate was high in 2017 (92.5\%) when compared with 2018 $(39.58 \%)$ as shown in the table (1).

The distribution of congenital anomalies according to the months of the years under study were revealed in figure (1), where the results showed that the highest percentage in November 2017 (7) cases, while the highest percentage in the June 2018 was (9). 
Thi-Qar Medical Journal (TQMJ):Vol.(19), No.(1), 2020

Web Site: $\underline{\text { https://jmed.utq.edu.iq }}$

Email:utjmed@utq.edu.iq

ISSN (Print):1992-92 18, ISSN (Online):1992-92 18

DOI: https://doi.org/10.32792/utq/utjmed/19/1/3/0

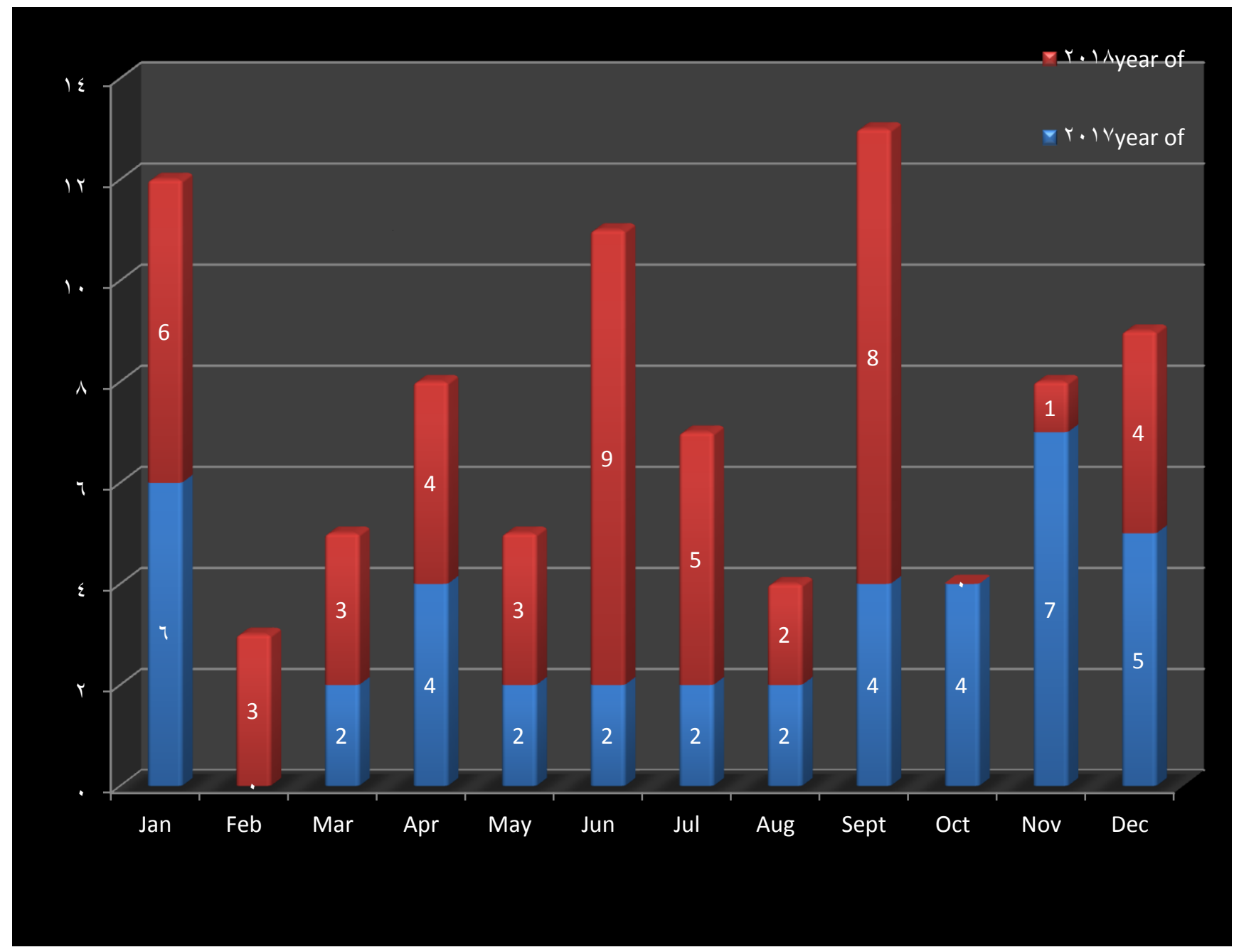

Figure 1: Distribution congenital anomalies according to the months of the 2 years of the study.

The distribution according to the types of congenital anomalies, where the results showed the highest percentage: spina bifida(0.88) in 2018. The results also showed a hydrocephalus and cleft lip ratio of 0.71 in 2018, while distribution was of multiple distortions, the rate was high $(0.46)$ in 2017.While distribution was of CHD and pul Atresia, the rate was high(0.5) in 2017 and 2018 as shown in Figure (2). 
Thi-Qar Medical Journal (TQMJ):Vol.(19), No.(1), 2020

Web Site: https://jmed.utq.edu.iq

Email:utjmed@utq.edu.iq

ISSN (Print):1992-92 18, ISSN (Online):1992-92 18

DOI: https://doi.org/10.32792/utq/utjmed/19/1/3/0

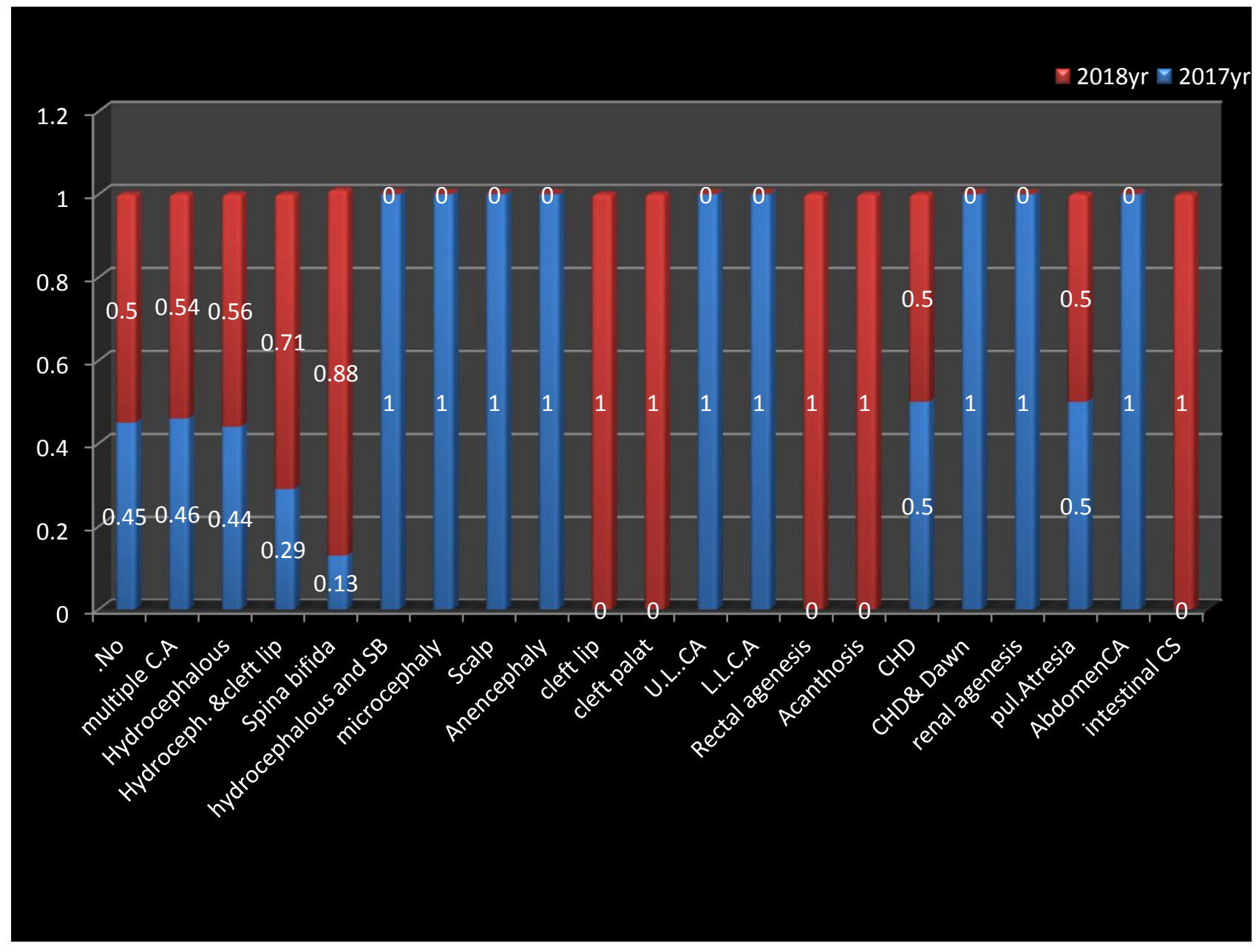

Figure 2: Distribution according to types of congenital anomalies

The results also revealed a high rate of deaths in November 2017 in 7(18.919) cases, and a high rate of September 2018 in 4(21.055). These results were significantly between percent death in 2017,2018 at $\mathrm{p}$. value $(\mathrm{P} \leq 0.05)$ as shown in table $(2)$. 
Thi-Qar Medical Journal (TQMJ):Vol.(19), No.(1), 2020

Web Site: https://jmed.utq.edu.iq

Email:utjmed@utq.edu.iq

ISSN (Print):1992-92 18, ISSN (Online):1992-92 18

DOI: https://doi.org/10.32792/utq/utjmed/19/1/3/0

Table(2) Distribution congenital anomalies according to percent death in 2017,2018

\begin{tabular}{|c|c|c|c|c|c|}
\hline Months & $\begin{array}{l}\text { Death at } \\
2017\end{array}$ & percent2017 & $\begin{array}{l}\text { Death at } \\
2018\end{array}$ & percent2018 & $P$ value \\
\hline Jan & 6 & 16.216 & 3 & 15.789 & \multirow[t]{13}{*}{$p<0.0341$} \\
\hline Feb & 0 & 0.0 & 1 & 5.263 & \\
\hline Mar & 2 & 5.405 & 2 & 10.526 & \\
\hline Apr & 3 & 8.109 & 2 & 10.526 & \\
\hline May & 2 & 5.405 & 1 & 5.263 & \\
\hline Jun & 2 & 5.405 & 2 & 10.526 & \\
\hline Jul & 2 & 5.405 & 2 & 10.526 & \\
\hline Aug & 2 & 5.405 & 0 & 0.0 & \\
\hline Sept & 2 & 5.405 & 4 & 21.055 & \\
\hline Oct & 4 & 10.811 & 0 & 0.0 & \\
\hline Nov & 7 & 18.919 & 0 & 0.0 & \\
\hline Dec & 5 & 13.515 & 2 & 10.526 & \\
\hline Total & 37 & $100 \%$ & 19 & $100 \%$ & \\
\hline
\end{tabular}

Table 3: Distribution congenital anomalies according to types of delivery in 2017,2018

\begin{tabular}{|l|c|c|c|c|c|c|c|c|}
\hline & CS2017 & Percent & NVD2017 & Percent & CS2018 & Percent & NVD2018 & Percent \\
\hline Jan & 3 & 0.103448 & 3 & 0.272727 & 6 & 0.193548 & 0 & 0 \\
\hline Feb & 0 & 0 & 0 & 0 & 3 & 0.096774 & 0 & 0 \\
\hline Mar & 2 & 0.068966 & 0 & 0 & 2 & 0.064516 & 1 & 0.058824 \\
\hline Apr & 2 & 0.068966 & 2 & 0.181818 & 1 & 0.032258 & 3 & 0.176471 \\
\hline May & 2 & 0.068966 & 0 & 0 & 2 & 0.064516 & 1 & 0.058824 \\
\hline Jun & 2 & 0.068966 & 0 & 0 & 6 & 0.193548 & 3 & 0.176471 \\
\hline Jul & 0 & 0 & 2 & 0.181818 & 3 & 0.096774 & 1 & 0.058824 \\
\hline Aug & 2 & 0.068966 & 0 & 0 & 1 & 0.032258 & 1 & 0.058824 \\
\hline Sept & 2 & 0.068966 & 2 & 0.181818 & 6 & 0.193548 & 3 & 0.176471 \\
\hline Oct & 4 & 0.137931 & 0 & 0 & 0 & 0 & 0 & 0 \\
\hline Nov & 6 & 0.206897 & 1 & 0.090909 & 0 & 0 & 1 & 0.058824 \\
\hline Dec & 4 & 0.137931 & 1 & 0.090909 & 1 & 0.032258 & 3 & 0.176471 \\
\hline total & 29 & 1 & 11 & 1 & 31 & 1 & 17 & 1 \\
\hline P & $\mathbf{0}$ & & & & & & &
\end{tabular}

$P$ value $=0.021$ 
Thi-Qar Medical Journal (TQMJ):Vol.(19), No.(1), 2020

Web Site: $\underline{\text { https://jmed.utq.edu.iq }}$

Email:utjmed@utq.edu.iq

ISSN (Print):1992-92 18, ISSN (Online):1992-92 18

DOI: https://doi.org/10.32792/utq/utjmed/19/1/3/0

Table 4: Distribution congenital anomalies according to Gender in $2017 \& 2018$

\begin{tabular}{|l|r|r|r|r|r|l|l|l|}
\hline & $\begin{array}{l}\text { Male- } \\
\text { 2017 }\end{array}$ & percent & $\begin{array}{l}\text { Female } \\
\mathbf{2 0 1 7}\end{array}$ & percent & $\begin{array}{l}\text { Male } \\
\mathbf{2 0 1 8}\end{array}$ & percent & \multicolumn{2}{l|}{ Female 2018 } \\
\hline Jan & 2 & 0.086957 & 4 & 0.235294 & 2 & 0.111111 & 3 & 0.115385 \\
\hline Feb & 0 & 0 & 0 & 0 & 1 & 0.055556 & 2 & 0.076923 \\
\hline Mar & 0 & 0 & 2 & 0.117647 & 2 & 0.111111 & 1 & 0.038462 \\
\hline Apr & 1 & 0.043478 & 3 & 0.176471 & 1 & 0.055556 & 2 & 0.076923 \\
\hline May & 2 & 0.086957 & 0 & 0 & 1 & 0.055556 & 2 & 0.076923 \\
\hline Jun & 2 & 0.086957 & 0 & 0 & 2 & 0.111111 & 6 & 0.230769 \\
\hline Jul & 2 & 0.086957 & 0 & 0 & 2 & 0.111111 & 2 & 0.076923 \\
\hline Aug & 2 & 0.086957 & 0 & 0 & 0 & 0 & 2 & 0.076923 \\
\hline Sept & 3 & 0.130435 & 1 & 0.058824 & 5 & 0.277778 & 3 & 0.115385 \\
\hline Oct & 3 & 0.130435 & 1 & 0.058824 & 0 & 0 & 0 & 0 \\
\hline Nov & 3 & 0.130435 & 4 & 0.235294 & 0 & 0 & 1 & 0.038462 \\
\hline Dec & 3 & 0.130435 & 2 & 0.117647 & 2 & 0.111111 & 2 & 0.076923 \\
\hline total & 23 & 1 & 17 & 1 & 18 & 1 & 26 & \\
\hline
\end{tabular}

$P$ value $=0.003$

\section{Discussion :}

Most children born with birth defects affected by childhood survive physically, mentally or socially and may be at increased risk due to many health disorders[10].Congenital anomalies differ in their types and causes. This may be due to genetic, environmental and racial factors. There are $66 \%$ of congenital anomalies known to cause[11].In a previous study conducted by AlSaadi et al.,(2013) in Baghdad, Iraq, where they found the percentage of birth defects for males 42 (70.0\%)[12], and this percentage agree with the current study percentage in 2018 $27(56.25 \%)$, where we found the percentage of females with congenital anomalies 18 (30.0\%) this results disagree with the current study in the year 201723 (57.5\%). The proportions may differ according to geographical and environmental factors, genetic and ethnic backgrounds, and nutritional, social and economic differences.Also, there is a previous

study conducted byAdel $\mathrm{j}$. Hussein, (2009) in Diwaniyah, where they found the percentage of females who suffer from congenital anomalies $47(0.6 \%)$ and this percentage correspond to the current study, while the congenital anomalies in males were $114(2.4 \%)$, and this percentage disagree to the current study. There is a study by Ochieng et al, (2011)where he found the percentage of hermaphrodites of congenital anomalies 1(100\%), and this proportion disagree with the current study in 2018. While hydrocephalus found the ratio $1(2.9 \%)$, and this ratio corresponds to the current study. 
Web Site: $\underline{\text { https://jmed.utq.edu.iq }}$

ISSN (Print):1992-92 18, ISSN (Online):1992-92 18

DOI: https://doi.org/10.32792/utq/utjmed/19/1/3/0

Also, there are previous study by Ameen et al., (2018) they found the percentage of

Hydrocephalus 16(12.3\%), these result high than percentage of the current study. According to a previous study by Adel j. Hussein, (2009)

found in it a cleft lip ratio of (0.56), this percentage does not correspond to the current study in 2017 (0.29\%), while it corresponds to the current study in $2018(0.71 \%)$. While the percentage of hydrocephalus $(0.48 \%)$, and this proportion corresponds to the current study in the year $2017(0.44 \%)$.It differed in the year 2018 when the current study percentage was $(0.56 \%)$.As well as the percentage of infection with Down syndrome they found 18 (11.1\%) and this percentage dis agree with current study.Perhaps the cause of birth defects due to many factors, including kinship is considered a major risk factor, as well as the age of the mother[14]. Also, a previous study confirmed by Al-rawi, (2012) in Anbar found that the clefts lip rate was $60 \%$, and this disagree my current study. May be the cause of birth defects due to taking drugs during pregnancy, or it may be due to a genetic defect in the early stages of fetal formation[16]. There are large quantities of toxic minerals pumped into the Iraqi environment through wars, where uranium used in bombs and bullets has been detected in the tissues of the Iraqi people, which in turn may be the warmest cause of birth defects[17].However, this difference is most likely due to the difference in the study design.Also there is a previous study by Parmar et al., (2010) they found the proportion of deceased birth defects $(13.30 \%)$, and this ratio corresponds to the current study.Also, there is a previous study by Morris et al.,
Email:utjmed@utq.edu.iq (2014)confirmed that those with Down syndrome are more than $40 \%$ and are likely to have other birth defects and confirmed that 42.4-44.7\% suffer from Down syndrome with anomaly of the heart and the females with

Down syndrome were more than males with this disease and this study disagree with the

current study.A study byAmeen et al., (2018) they found the percentage of down syndrome $3(2.3 \%)$, these results agree with the result of the current study. A previous study bySingh et $a l .$, (2014), they found the percentage of down syndrome are $26(6.9 \%)$,this study disagree with the current study. as well, they found the percentage of Cleft lip and palate 25 (6.6\%), this result disagree with current study in 2017 while agree with current study in 2018 and they found the percentage ofSpina bifida19 (5.1\%), this percentage agree with current study in 2017 while disagree with study in 2018. Perhaps the reason for the different proportions and the different types of congenital anomalies is due to many factors, including inbreeding, the mother's age, or late pregnancy, as well as drugs.It is also difficult to determine the cause of the diversity of deformities and their increase in 2018, which may be due to geographical variation for a period of two years, or caesarean section may be one of the reasons for diversity, as it was noted in the current study that the deformities increased in 2018 31(64.58\%)compared to 2017.Also, congenital malformations may be cleft lip or cleft palate, which may be due to consuming cigarettes by the mother during pregnancy, as well, Abnormalities in the nervous system may occur due to not eating foods rich in folic acid during pregnancy, where exposure to nicotine 
Web Site: https://jmed.utq.edu.iq
Email:utjmed@utq.edu.iq

\section{ISSN (Print):1992-92 18, ISSN (Online):1992-92 18 \\ DOI: https://doi.org/10.32792/utq/utjmed/19/1/3/0}

from smoking and carbon monoxide can be the cause of these defects because of the lack of oxygen[20].The results of this study illustrated that the loss of prenatal care. An increase in caesarean was detected in recent years. It is a negative hint of the possibility of future abnormalities. There is a prior article conducted by Alaarji, (2017) in karbala he establish the

percentage of congenital anomalies in the heart $33(42.86 \%)$, and this ratio is more than those of

the present study rate of 0.5 over the 2017 and 2018 years. A previous study by Kamal and

Othman, (2018) found the rate of cardiac anomaly was $(24.2 \%)$ which is high when compare with the current study over two years. The difference in results may be due to malnutrition, industrial and environmental pollution. Also, the current study is agree with the previous study in the ratio Anencephaly $1(1.3 \%)$ in 2017.According to this study, they also found the percentage of Spina bifida 46 (7.8), Hydrocephalus 31 (5.3 )andAnencephaly 61.0 ,Where the current study agree with the ratio of Spina bifida in 2017 and not in 2018, the current study disagree with the proportion of Hydrocephalus, and it agree with to the ratio of Anencephaly in 2017. A low mortality rate for children with congenital malformation was observed in 2018, in the current study, which may be due to spina bifida, Down syndrome, or a birth defect that can be surgically adjusted. Where a previous study was

conducted by Hameed and Abed, (2012) they found an increase in the death rate over two consecutive years for children with congenital anomalies while in the current study we found a decrease in the death rate over two consecutive years.

\section{Conclusion:}

1-SBR is differ according to gender (males- at 2018, females in 2017), SBR is differ according to BW ( weighing > 4kg -at 2017, < $4 \mathrm{~kg}-2018$ and The CS comprise high percent of SBR.

2- according to their presentation anomalies were arranged in different annual way 3-Spina bifida, hydrocephalous, CHD and pul Atresia were more common yearly Recommendation: necessity to provides important background information for potential prevention and better management of female who may have children with birth defects and the importance of further researches is required to determine the factors responsible for different types of birth defects.

\section{References:}

1- J. Ochieng, H. Kiryowa, I. Munabi, and C. B. R. Ibingira, "Prevalence, Nature and Characteristics of External Congenital anomalies at Mulago Hospital," j. surg., vol. 16, no. 11, p. 2073, 2011.

2- $\quad$ S. K. Ameen, S. K. Alalaf, and N. P. Shabila, "Pattern of congenital anomalies at birth and their correlations with maternal characteristics in the maternity teaching hospital, Erbil city, Iraq," BMC Pregnancy Childbirth, vol. 2, no. 4, pp. 1-8, 2018. 
Web Site: $\underline{\text { https://jmed.utq.edu.iq }}$
Email:utjmed@utq.edu.iq

\section{ISSN (Print):1992-92 18, ISSN (Online):1992-92 18}

DOI: https://doi.org/10.32792/utq/utjmed/19/1/3/0

3- $\quad$ R. Lozano et al., "Global and regional mortality from 235 causes of death for 20 age groups in 1990 and 2010: a systematic analysis for the Global Burden of Disease Study 2010," Lancet 2012, vol. 380, no. 12, pp. 2095-2128, 2010.

4- M. Pastor-garcía, S. Gimeno-martos, Ó. Zurriaga, J. V Sorlí, and C. Cavero-carbonell, "Congenital heart defects in the Valencian Region 2007- -2014 : The population-based registry of congenital anomalies," An. Pediatría, vol. 92, no. 1, pp. 13-20, 2020.

5- $\quad$ S. Alaani, M. A.R., and M. Hamdan, "Pilot Study of Congenital Anomaly Rates at Birth in Fallujah, Iraq, 2010ळ," JIMA, vol. 44, no. 12, pp. 1-7, 2012.

6- $\quad$ M. Savabieasfahani, F. B. Ahamadani, and A. M. Damghani, "Living near an active U . S . military base in Iraq is associated with signi fi cantly higher hair thorium and increased likelihood of congenital anomalies in infants and children," Environ. Pollut., vol. 256, no. 6, p. $113070,2020$.

7- $\quad$ A. Parmar, S. P. Rathod, S. V Patel, and S. M. Patel, "A Study of Congenital Anomalies In Newborn Original,” NJIRM, vol. 1, no. 1, pp. 13-17, 2010.

8- $\quad$ S. Liu, M. S. Kramer, and A. C. Allen, "and Pregnancy Termination to Overall Infant Mortality in Canada," Orig. Contrib., vol. 287, no. 12, pp. 1561-1567, 2002.

9- S. Dastgiri, D. H. Stone, and W. H. Gilmour, "Prevalence and secular trend of congenital anomalies in Glasgow, UK," Arch Dis Child, vol. 8, no. 6, pp. 257-263, 2002.

10- G. O. Othman, "The prevalence and types of congenital anomalies in newborns in erbil . Med. J. Islam. World Acad. Sci., vol. 21, no. 1, p. 34, 2016.

11- L. D. Botto, M. C. Lynberg, and J. D. Erickson, "Congenital Heart Defects, Maternal Febrile Illness, and Multivitamin Use : A Population-Based Study,” Epidemiology, vol. 12, no. 5, pp. 485-490, 2001.

12- Y. I. ALSaadi, M. B. Naoom, Y. B. A. Ghalib, and H. Y. Matloob, "Congenital Anomalies among Newborns Admitted in Tertiary Hospital ; Iraqi Experience," Fac Med Baghdad, vol. 55, no. 2, pp. 106-110, 2013.

13- Adel j. Hussein, "The Prevalence of congenital malformations among live births in Diwaniyah , Iraq,” Kufa Med.Journal, vol. 12, no. 2, pp. 204-211, 2009.

14- K. k. Alaarji, "Risk factors of congenital anomalies in Karbala," AL-Qadisiya Med. J., vol. 13, no. 24, 2017.

15- M. K. Al-rawi, “Cleft Lip and Palate in Anbar Province,” Anb Med J, vol. 10, no. 2, pp. 92-95, 2012.

16- asia humood Huiseen, "Identify factors affecting the incidence of congenital deformities in newborns In Baghdad city, using logistic regression," kut sicnces, vol. 26, no. 6, pp. 1-14, 
Thi-Qar Medical Journal (TQMJ):Vol.(19), No.(1), 2020

Web Site: $\underline{\text { https://jmed.utq.edu.iq }}$

\section{ISSN (Print):1992-92 18, ISSN (Online):1992-92 18 \\ DOI: https://doi.org/10.32792/utq/utjmed/19/1/3/0}

2017.

\section{Email:utjmed@utq.edu.iq}

17- R. Abdullah, L. Yaqup, H. S. Al-salih, and D. Godbold, "Environmental pollution by depleted uranium in Iraq with special reference to Mosul and possible effects on cancer and birth defect rates," Med. Confl. Surviv., vol. 29, no. 1, pp. 7-25, 2013.

18_ J. K. Morris et al., "Major Congenital Anomalies in Babies Born With Down Syndrome : A Euroaat Population-Based Registry Study,” Med. Genet., vol. 7, no. 12, pp. 4-11, 2014.

19- K. Singh, K. Krishnamurthy, C. Greaves, L. Kandamaran, A. L. Nielsen, and A. Kumar, "Major Congenital Malformations in Barbados: The Prevalence, the Pattern, and the Resulting Morbidity and Mortality,” ISRN Obstet. Gynecol. Live, vol. 5, no. 2, p. 8, 2014.

20- M. A. Honein et al., "Maternal Smoking and Environmental Tobacco Smoke Exposure and the Risk of Orofacial Clefts,” Epidemiology, vol. 18, no. 2, pp. 226-233, 2016.

21- N. M. Kamal and N. Othman, "Incidence and Types of Congenital Anomalies in Newborns in Sulaimaniyah City, Iraq,” Medica Iran., vol. 56, no. 12, pp. 769-766, 2018.

22- N. N. Hameed and B. N. Abed, "Descriptive Study of Neonatal Death in Neonatal Care Unit of Baghdad Teaching Hospital / Medical city / Baghdad ( 2007-2009 )," J Fac Med Baghdad, vol. 54, no. 3, pp. 214-217, 2012.
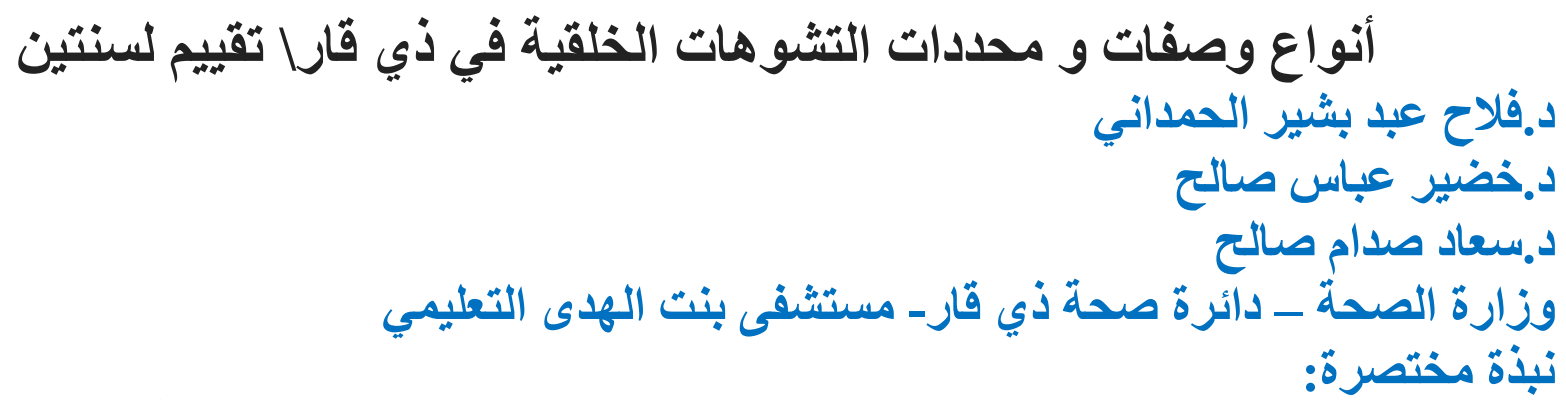

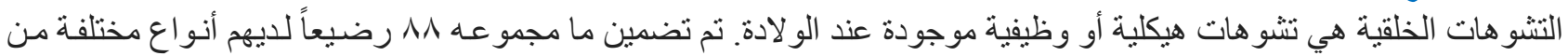

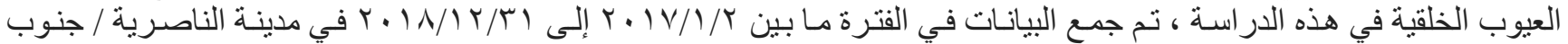

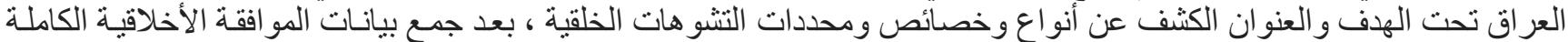

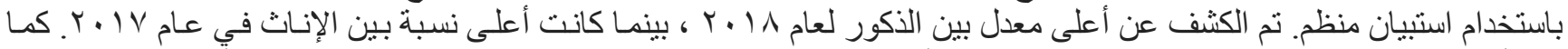

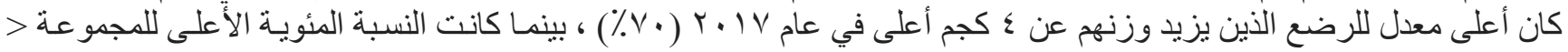

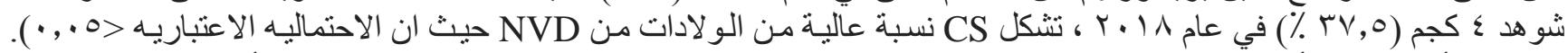

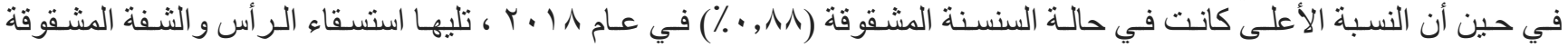

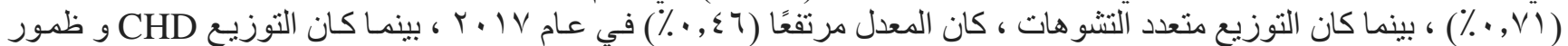

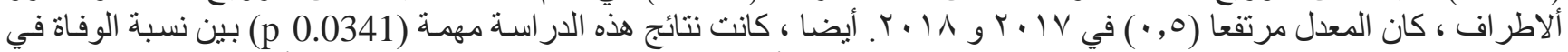

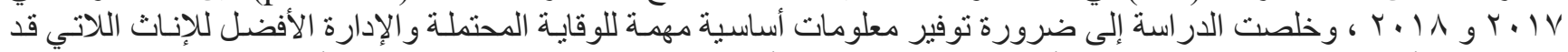

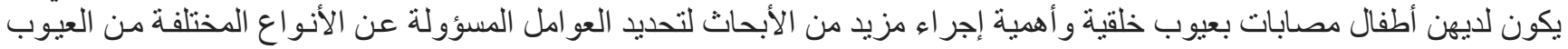
الخلقية.

الكلمات الرئيسية: التشوهات الخلقية ، العمليات القيصريه ،ذي قار 2018-2017 